\title{
Pengenalan literasi media untuk pencegahan konflik sosial pada siswa sekolah dasar di wilayah perdesaan
}

\section{Leadya Raturahmi ${ }^{1 \star}$, R. Ismira Febrina ${ }^{2}$, Rosanti Utami Dewi SY ${ }^{3}$}

\author{
1Universitas Garut, Indonesia, email: leadyaraturahmi@uniga.ac.id \\ 2Universitas Garut, Indonesia, email: ismirafebrina@uniga.ac.id \\ 3Universitas Garut, Indonesia, email: rosantiutamidewi@uniga.ac.id \\ *Koresponden penulis
}

\section{Info Artikel}

Diajukan: 06 Jul 2021

Diterima: 15 Nov 2021

Diterbitkan: 23 Nov 2021

Keywords:

media literacy; rural society; persuasive communication

Kata Kunci:

literasi media; masyarakat perdesaan; komunikasi persuasif

Lisensi:

cc-by-sa

\begin{abstract}
Human development in the field of education is very important because it relates to the quality of human life in other fields, one of which is on the social aspects, especially those related to children. The condition that occurs in children today is the high use and negative exposure of mass media, especially from the use of television and the internet. The high use of this media is not accompanied by adequate skills in children regarding access and ability to analyze the content of media messages so that negative impacts of use appear, including social conflicts between children in their environment. The purpose of this activity is to introduce the ability to access, analyze, evaluate and communicate messages in various forms of communication and information media for the prevention of social conflict in children. The method of carrying out activities using lecture, demonstration, and discussion methods. The subject of the activity is elementary school age children in Panembong Village, Bayongbong District, Garut Regency. The implementation process is carried out with the assessment stage, the implementation stage, and the assessment stage as well as the evaluation stage. The results of this activity illustrate the existence of better knowledge and understanding of elementary school age children in accessing, analyzing, evaluating and communicating messages in various forms of communication and information media, especially to prevent social conflict between peers.
\end{abstract}

\section{Abstrak}

Pembangunan manusia dalam bidang pendidikan merupakan hal yang sangat penting karena berkaitan dengan kualitas kehidupan manusia pada bidang lainnya, salah satunya adalah pada aspek sosial terutama yang berkaitan dengan anak. Kondisi yang terjadi pada anak saat ini adalah tingginya penggunaan dan paparan negatif media massa terutama dari penggunaan televisi dan internet. Tingginya penggunaan media ini tidak disertai dengan kemampuan yang memadai pada anak mengenai cara akses dan kemampuan analisis isi pesan media sehingga muncul dampak negatif penggunaan diantaranya berupa konflik sosial antar anak dalam lingkungannya. Tujuan kegiatan ini adalah pengenalan kemampuan dalam mengakses, menganalisis, mengevaluasi dan mengkomunikasikan pesan dalam berbagai bentuk media komunikasi dan informasi untuk pencegahan konflik sosial pada anak. Metode pelaksanaan kegiatan dilakukan dengan menggunakan metode ceramah, demonstrasi, dan diskusi. Sasaran kegiatan adalah anak usia sekolah dasar di Desa Panembong Kecamatan Bayongbong Kabupaten Garut. Proses 
pelaksanaan dilakukan dengan tahap perencanaan, tahap pelaksanaan, dan tahap penilaian serta tahap evaluasi. Hasil dari kegiatan ini menggambarkan adanya pengetahuan dan pemahaman yang lebih baik pada anak usia sekolah dasar dalam mengakses, menganalisis, mengevaluasi dan mengkomunikasikan pesan dalam berbagai bentuk media komunikasi dan informasi terutama untuk mencegah konflik sosial antar sebaya.

\section{PENDAHULUAN}

Pemberdayaan masyarakat sebagai bagian dari proses pembangunan merupakan tanggung jawab bersama dan membutuhkan partisipasi aktif dari anggota masyarakat. Partisipasi aktif ini akan terlaksana dengan baik jika disertai dengan pengetahuan dan pemahaman masyarakat akan masalah yang terjadi dalam kehidupan di sekitar mereka. Salah satu permasalahan dalam kehidupan masyarakat adalah kurangnya pemahaman mengenai literasi media sebagai akibat dari penggunaan teknologi infomasi dan komunikasi yang menyebar luas dalam kehidupan masyarakat. Kabupaten Garut sebagai kabupaten yang masyarakatnya bercirikan taqwa, maju, dan sejahtera mulai mengalami tantangan pembangunan terutama pada anak. Salah satu permasalahan yang muncul akibat dari penggunaan teknologi informasi dan komunikasi pada anak adalah adanya konlik sosial antar sebaya yang diakibatkan peniruan dari konten media yang diakses oleh anak saat menggunakan perangkat teknologi informasi secara berlebihan dan tanpa pendampingan orang tua maupun guru.

Kondisi penggunaan perangkat teknologi dan informasi ini salah satunya ditemukan di Desa Panembong, Kecamatan Bayongbong, Kabupaten Garut. Desa ini berdiri pada bulan Maret tahun 1984, hanya berjarak sekitar 9 $\mathrm{km}$ dari pusat kota kabupaten dan telah memiliki akses teknologi informasi yang cukup baik. Panembong berasal dari kata dasar Nembong yang artinya memperlihatkan keunggulan dan kejayaan masyarakat. Hal ini sejalan dengan potensi yang dimiliki Desa Panembong ini yaitu dalam bidang pertanian serta industri rumah tangga berupa rajutan dan konveksi yang berhasil memajukan tingkat pendapatan ekonomi masyarakat desa. Dengan kondisi perekomonian yang baik dan akses yang juga terhubung dengan baik ke pusat kota, membuat masyarakat desa dengan mudah menikmati fasilitas pembangunan dengan baik, salah satunya adalah pada akses teknologi informasi. Akses ini tidak hanya dinikmati oleh anggota masyarakat dewasa, tapi juga anak-anak. Meskipun tinggal di wilayah di perdesaan, anak-anak di desa ini diketahui rutin menonton televisi, dan mampu mengakses internet secara mandiri baik melalui perangkat pribadi, maupun meminjam milik orang tua.

Kondisi ini tentu membutuhkan perhatian bersama, terutama dalam mencegah dampak negatif yang diakibatkan oleh penggunaan perangkat teknologi informasi secara tidak tepat pada anak. Dengan potensi jumlah pelajar tingkat dasar yang cukup banyak, yaitu di Sekolah Dasar Negeri Panembong 1 dan Panembong 2 dengan total peserta didik sejumlah 680 siswa, maka dibutuhkan suatu pendampingan dari orang dewasa untuk membantu anak dalam meluruskan pemahaman mereka atas tayangan program televisi maupun internet yang berpotensi memberikan dampak negatif 
pada anak serta menjauhkan anak dari pembentukan karakter diri yang religius, maju, dan sejahtera sesuai dengan ciri masyarakat Garut.

Dalam penggunaan media pada anak-anak di Desa Panembong, muncul persoalan yang berkaitan dengan dampak negatif pesan media. Anak tanpa disadari terpapar budaya kekerasan dari media, mengalami kematangan seksual yang lebih awal akibat menonton tayangan yang tidak sesuai batas usianya, serta serta konflik sosial berupa kekerasan antar sebaya seperti menghina, memukul, atau berkelahi antar teman. Berdasarkan hasil beberapa penelitian sebelumnya, ditemukan bahwa permasalahan pada konten media yang tidak mendidik ini, salah satunya berkaitan dengan rendahnya keterlibatan orang tua dalam pendampingan dan pendidikan literasi digital yang rendah pada anak (Munawar et al., 2019). Anak cenderung melakukan imitasi perilaku dan peniruan verbal negatif terhadap lingkungan sosialnya sebagai dampak dari penggunaan media massa (Astarini et al., 2017). Kemudian juga salah satu penyebab munculnya perilaku negatif pada anak dipicu oleh peniruan tayangan negatif media massa, seperti misalnya dengan menganggap perkataan atau tindakan tertentu tidaklah menyakiti tapi hanya sebagai candaan saja (Kunandar, 2014). Hal ini bisa dianggap sebagai sesuatu yang umum atau biasa saja, akan tetapi jika dibiarkan maka akan berkembang dari sekedar konflik sosial antar sebaya yang dapat memicu konflik sosial yang lebih luas dalam masyarakat.

Konflik dapat dilihat sebagai perjuangan antar individu atau kelompok untuk memenangkan sesuatu tujuan yang sama-sama ingin mereka capai dengan tujuan untuk penghancuran pihak lawan, di mana potensi konflik ditandai oleh adanya perasaan tertekan dan tidak mampu menolak perbuatan pihak lawan (Suparlan, 2006). Dalam konflik sosial pada anak yang berkaitan dengan dampak penggunaan media massa, diketahui terdapat beberapa situasi potensi konflik yaitu pada ciri fisik, keterbatasan sosial, serta aspek keagamaan seseorang yang dipresentasikan anak melalui tindakan dan ucapan negatif pada rekannya (Kunandar, 2014). Selain banyaknya dampak negatif dari tayangan di televisi, masalah lain adalah adanya informasi palsu atau hoax yang berseliweran di internet (Mas'Amah \& Hana, 2018).

$\mathrm{Hal}$ ini tentu menjadi masalah serius dalam perkembangan anak yang terkait dengan dampak media massa, terutama anak di wilayah perdesaan. Masyarakat di perdesaan cenderung memiliki frekuensi akses yang tinggi pada media namun memiliki kemampuan literasi media tergolong sedang, terlebih karena mereka hanya mengakses pada konten dengan unsur hiburan saja (Novianti \& Riyanto, 2018). Kemudian kemampuan anak dalam menganalisis isi pesan media sesungguhnya masih sangat terbatas, di mana anak belum menyadari bahwa realitas di media massa dikonstruksikan sedemikian rupa berdasarkan ekonomi politik media massa (Setyaningsih, 2017). Televisi yang sebagian besar di Indonesia memiliki program tayangan sinetron untuk dewasa, tak menghalangi anak-anak tetap untuk menonton sinetron tersebut (Hariyanti, 2017).

Tayangan televisi ataupun tayangan audiovisual di internet membuat seseorang, terutama anak-anak dapat betah menonton lama di depan layar 
televisi, terlebih jika anak memang tidak memiliki banyak aktivitas lainnya dalam keseharian mereka. Rata-rata anak menoton televisi setiap harinya lebih dari 5 jam dalam sehari, mulai pada pagi hari siang sehabis pulang sekolah dan malam hari dan terkadang sampai lupa waktu (Hariyanto, 2018). Kemudian anak bisa mengalami gangguan emosi seperti rasa ketakutan berlebihan, phobia, serta anak menjadi tidak mandiri yang diakibatkan dari tingginya frekuensi menonton tayangan dengan konten negative (Musfira, 2018). Selain itu intensitas dan frekuensi yang tinggi saat menggunakan perangkat teknologi informasi dan komunikasi membuat anak jadi terganggu secara fisiknya seperti mata yang perih, postur tubuh berubah, kulit wajah yang kendur, pendengaran terganggu, serta mengalami gangguan pola istirahat (Chusna, 2017).

Sesungguhnya teknologi informasi dan komunikasi adalah media yang baik dalam membangun interaksi dan relasi antar individu, sekaligus sebagai sumber informasi dan hiburan (Rahardjo et al., 2012). Berdasarkan penelitian yang telah dilakukan oleh pelaksana sebelumnya, bahwa di wilayah perdesaan, televisi adalah bentuk media massa yang populer dan sayangnya sebagian besar pengguna tidak mengetahui dampak negatif dari media yang mereka gunakan tersebut (Raturahmi, 2018). Televisi dan internet menyajikan tampilan audio visual yang lebih menarik dan menghibur dibandingkan dengan bentuk media lainnya seperti radio atau surat kabar.

Dengan terpaan media yang tinggi pada masyarakat perdesaan ini, maka dibutuhkan suatu upaya pengenalan penggunaan media yang memberdayakan anggota masyarakat karena pemanfaatan media ini tidak hanya untuk berkomunikasi tapi juga berperan dalam peningkatan kualitas hidup masyarakat. Sejauh ini, upaya negara dalam membebaskan bangsa dari keterbelakangan belum menghasilkan sesuatu yang optimal yang salah satunya berkaitan erat dengan tidak dimasukkannya modal sosial dalam hal ini berupa niat baik, rasa simpati, perasaan persahabatan, dan hubungan sosial sebagai faktor penting dalam mempengaruhi efisiensi dan efektivitas kebijakan (Bilu et al., 2018). Pengenalan literasi media ini, dapat menjadi salah satu modal sosial bagi masyarakat dalam membangun hubungan sosial yang lebih positif atas terpaan media.

Seringkali literasi media pada anak terlupakan karena hanya berfokus pada orang dewasa saja. Anak sebagai pembelajar aktif yang jika mereka menyenangi apa yang dipelajarinya, maka hasil pembelajaran akan menjadi efektif (Triwardhani, 2006). Literasi media sendiri memiliki banyak definisi, salah satunya dikemukakan oleh Sonia Livingstone bahwa literasi media adalah kemampuan untuk mengakses, menganalisis, mengevaluasi dan mengkomunikasikan pesan dalam berbagai bentuk medium (Hendriyani \& Guntarto, 2018). Dalam mengkomunikasikan pengenalan literasi, maka dibutuhkan suatu pendekatan persuasif kepada khalayak. Persuasi merupakan upaya pengubahan sikap individu dengan memasukkan ide, pikiran, pendapat, serta fakta baru lewat pesan-pesan komunikatif yang digunakan antara lain bersikap sejajar, memperbanyak diskusi, mengarahkan secara halus, mendampingi, serta mendengarkan keluh kesah (Triwardhani, 2006). 
Tujuan dari pelaksanaan kegiatan ini adalah pengenalan kemampuan dalam mengakses, menganalisis, mengevaluasi dan mengkomunikasikan pesan dalam berbagai bentuk media komunikasi dan informasi untuk pencegahan konflik sosial pada anak. Melalui pendekatan komunikasi persuasif, diharapkan anak dapat mengubah pemahaman dan perilakunya terutama yang berkaitan dengan imitasi negatif yang diperolehnya dari media. Berkaitan dengan kondisi diatas maka manfaat pelatihan literasi media ini adalah sebagai suatu langkah antisipatif bagi anak dalam mencegah dampak buruk media di kehidupan sosial mereka dan juga sebagai wujud kepedulian mengenai pentingnya meningkatkan wawasan masyarakat mengenai perilaku bijak dalam mengakses media komunikasi dan informasi.

\section{METODE PELAKSANAAN}

Metode pelaksanaan kegiatan dengan menggunakan metode ceramah, demonstrasi, dan diskusi. Subjek kegiatan adalah anak usia sekolah dasar di Desa Panembong Kecamatan Bayongbong Kabupaten Garut. Guna mencapai tujuan proteksionis dari pengenalan literasi media ini, pelaksana mengadopsi model yang ditawarkan oleh Rumah Sinema (Setyaningsih, 2017) di mana anak-anak diarahkan untuk memilih tontonan yang baik dan mengindarkan yang buruk dengan cara diet media dan pengaturan jadwal menonton. Proses pelaksanaan dilakukan dengan tahap persiapan, tahap pelaksanaan, dan tahap penilaian serta tahap evaluasi sebagaimana digambarkan dalam bagan berikut:

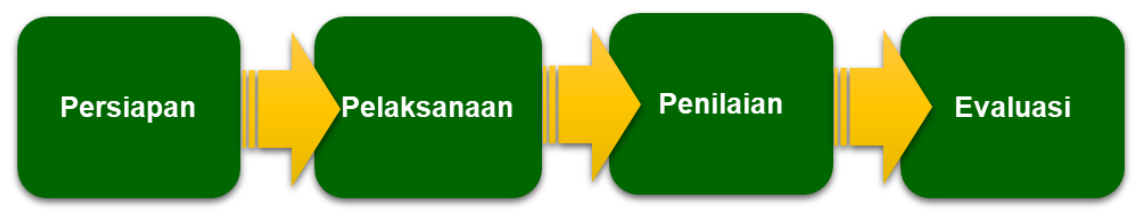

Gambar 1. Proses pelaksanaan pelatihan

\section{HASIL DAN PEMBAHASAN}

Hasil yang dicapai dari pengenalan literasi media melalui komunikasi persuasif pada anak usia sekolah dasar di Desa Panembong, Kecamatan Bayongbong, Kabupaten Garut dikelompokkan berdasar tahapan kegiatan. Kegiatan penyuluhan dilakukan dengan pendekatan komunikasi persuasif sesuai dengan tahapan usia perkembangan anak usia sekolah dasar. Informasi literasi media yang diberikan berfokus pada diet media dan pengaturan jadwal akses media. Kegiatan dihadiri oleh siswa kelas 5-6 dengan pertimbangan bahwa mereka telah memiliki kemampuan dan kemandirian akses pada media massa. Selama berjalannya seluruh proses, kegiatan berlangsung dengan baik, terlihat dukungan dari pihak sekolah dan aparatur desa dengan menyediakan sarana kegiatan. Antusiasme juga diberikan oleh peserta yang memperhatikan dengan seksama informasi yang disampaikan pelaksana. Pada sesi diskusi, peserta mampu melontarkan pertanyaan dan keluhan mengenai hubungan sosial sebaya di sekolah maupun di rumah, serta mampu menceritakan pengalaman mereka saat mengakses media massa, terutama tayangan televisi 
yang mereka sukai. Tahapan pelaksanaan ini dilakukan dengan persiapan, pelaksanaan, dan penilaian serta evaluasi.

Tahap persiapan dengan pengenalan literasi media untuk pencegahan konflik sosial pada siswa sekolah dasar di wilayah perdesaan merupakan kerjasama Program Studi IImu Komunikasi Universitas Garut dengan Desa Panembong Kecamatan Bayongbong Kabupaten Garut. Tahap persiapan ini meliputi observasi pendahuluan, izin pelaksanaan, penentuan tema yang sesuai dengan kebutuhan peserta, penentuan tanggal dan hari pelaksanaan, mempersiapkan ruang serta sarana prasarana yang mendukung dalam kegiatan.

Pelaksanaan kegiatan dilakukan pada Maret 2018 jauh sebelum pandemi Virus Corona 19 (Covid-19) melanda Indonesia. Pelaksanaan pelatihan ini dilaksanakan dalam 2 gelombang sesuai lokasi kegiatan yaitu di SDN Panembong 1 dan Panembong 2 dengan total keseluruhan 184 siswa sebagai sasaran kegiatan. Kegiatan di SDN Panembong 1 dimulai pukul 09.0011.30 WIB. Sedangkan kegiatan di SDN Panembong 2 dimulai puku $13.00-$ 15.30 WIB. Tempat pelatihan di SDN Panembong 1 dan SDN Panembong 2 Desa Panembong Kecamatan Bayongbong Kabupaten Garut. Durasi kegiatan pelatihan ini sekitar 2.5 jam/gelombang dengan penyampaian materi oleh 3 narasumber dari Prodi IImu Komunikasi Universitas Garut. Kegiatan meliputi 4 materi penyuluhan dan demonstrasi berupa: 1) Kriteria tayangan yang boleh ditonton oleh anak, 2) Kriteria frekuensi dan durasi akses media, 3) Alternatif kegiatan selain menonton televisi atau akes internet.

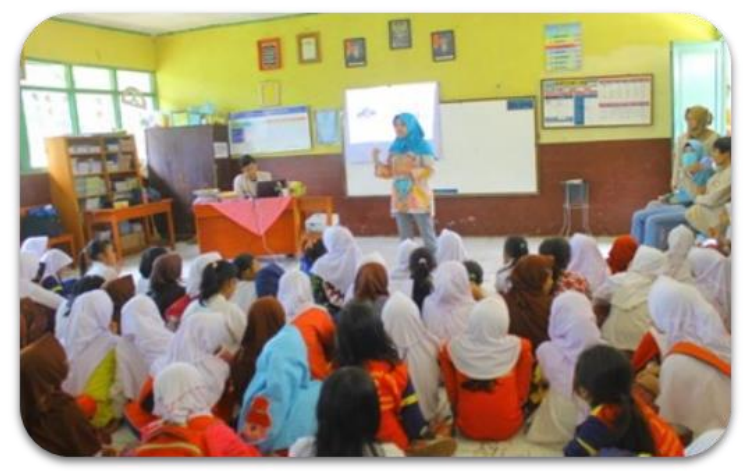

Gambar 2. Melakukan penyuluhan, demonstrasi, dan diskusi pada peserta kegiatan

Pemilihan materi ini merupakan hasil dari observasi kebutuhan peserta kegiatan yang masih merupakan anak-anak agar dapat diterima dengan mudah dan ringkas sehingga sasaran dapat secara mandiri memilih isi tayangan dan mengelola waktu penggunaan media. Tujuan dari pelaksanaan kegiatan ini meliputi kemampuan dalam mengakses, menganalisis, mengevaluasi dan mengkomunikasikan pesan dalam berbagai bentuk media komunikasi dan informasi untuk pencegahan konflik sosial pada anak. Kegiatan dilaksanakan dengan pendekatan komunikasi persuasif yaitu dengan cara bersikap sejajar dan mengarahkan secara halus kepada sasaran kegiatan. Demonstrasi 
dilakukan dengan memperagakan cara diet media dan pengaturan jadwal menonton kepada sasaran kegiatan. Diskusi dilakukan dengan mendampingi dan mendengarkan keluh kesah sasaran kegiatan.

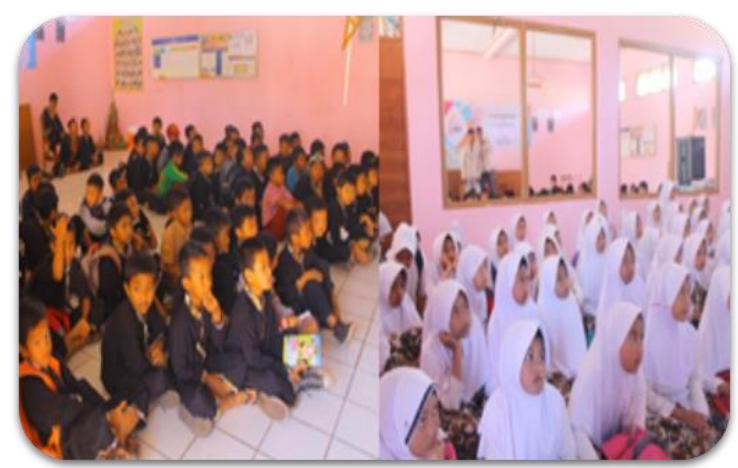

Gambar 3. Peserta saat mengikuti rangkaian kegiatan

Penilaian pada kegiatan ini menggunakan beberapa tahap meliputi: 1) Penilaian dari peserta sasaran kegiatan, 2) penilaian dari tim pelaksana dalam mengikuti kegiatan, keaktifan peserta selama sesi diskusi.

Tahap evaluasi ini merupakan tahapan evaluasi keseluruhan rangkaian kegiatan dimulai dari persiapan, pelaksanaan, dan penilaian. Tahap evaluasi pada persiapan meliputi: tahap kebutuhan peserta sasaran, kesiapan tim pelaksana dan mitra dalam menentukan program yang sesuai dengan tujuan kedua belah pihak. Pada tahap pelaksanaan, evaluasi dilakukan untuk melihat ketercapaian tujuan kegiatan meliputi: kehadiran peserta, keaktifan peserta, kesesuaian materi, penyampaian yang menarik, suasana yang kondusif, serta partisipasi aktif peserta selama sesi demonstrasi dan diskusi. Tahap evaluasi penilaian dilakukan pada efektivitas kegiatan, dan ketepatan waktu serta tujuan pelatihan yang sesuai dengan rencana kegiatan.

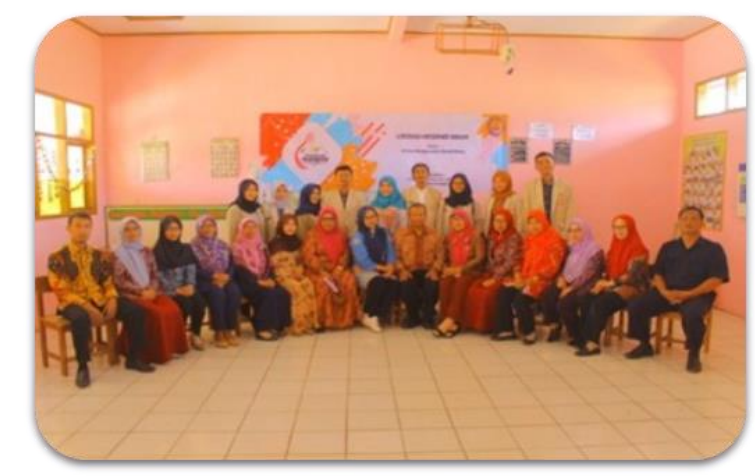

Gambar 4. Pelaksana bersama seluruh pendukung kegiatan

Selanjutnya adalah hasil yang dicapai dari program pengabdian masyarakat pada anak usia sekolah dasar di Desa Panembong, Kecamatan Bayongbong, Kabupaten Garut. Kegiatan penyuluhan yang dilaksanakan 
mendapat sambutan baik dari pihak sekolah maupun aparatur desa dengan menyediakan fasilitas pendukung kegiatan. Pada tahap ini pelaksana memaparkan informasi mengenai definisi literasi media, serta bagaimana melaksanakan pola diet media dan pengaturan jadwal mengakses media. Pelaksana melakukan pendekatan persuasif dengan berusaha tidak menggurui, menganggap khalayak sasaran sebagai teman, dan berusaha membangun kedekatan dengan khalayak sasaran. Dalam konteks literasi media untuk pencegahan konflik sosial, pelaksana memaparkan mengenai halhal yang perlu dihindari saat melihat tayangan media. Misalnya anak diarahkan untuk tidak mencontoh saat menonton televisi dengan tema acara hiburan yang menampilkan ucapan hinaan bentuk atau ciri fisik kepada lawan bicara, ejekan keterbatasan sosial seseorang, atau meniru adegan kekerasan seperti memukul atau menendang meskipun dengan dalih candaan semata. Informasi yang diberikan meliputi bahaya meniru tayangan negatif tersebut seperti anak menjadi sulit bermain dengan teman karena muncul konflik, kebiasaan melakukan kekerasan untuk mencapai tujuan, serta kemungkinan gangguan kesulitan konsentrasi akibat menonton televisi terlalu lama.

Saran diet media yang diberikan meliputi saran alternatif yang dikemukakan oleh Orange \& O'Flynn, (2005) bahwa anak bisa melakukan aktivitas lain seperti membaca buku, mengikuti kegiatan olahraga, kesenian, kelompok belajar, atau kegiatan keagamaan. Dengan lebih banyak aktivitas di luar, anak akan mengurangi jumlah jam menonton televisi atau akses internet, dan anak belajar mengatur kegiatan hariannya dengan lebih produktif. Materi disampaikan semenarik mungkin dalam suasana yang nyaman disertai dengan kuis dan hadiah ringan bagi anak yang bisa menjawab pertanyaan dalam sesi kegiatan. Dengan membangun suasana yang ringan, diharapkan peserta dapat menyenangi suasana sehingga lebih mudah menyerap informasi, untuk kemudian dapat masuk ke tahap pelaksanaan berikutnya.

Kegiatan demonstrasi dilaksanakan dengan memperagakan tayangan positif dan tayangan negatif dari media televisi. Pelaksana juga memperagakan tampilan sosial media yang layak maupun tidak layak diakses oleh anak. Pada tahap ini, pelaksana memeragakan secara setara dan halus mengenai bagaimana cara mengurangi jumlah jam menonton televisi atau mengakses internet, pada jam berapa anak boleh mengakses media, serta isi tayangan seperti apa yang layak ditonton. Pada demonstrasi ini juga diperagakan gambaran seseorang yang menampilkan ciri-ciri kecanduan media dengan mengadaptasi ciri yang dikemukakan oleh Orange \& O'Flynn (2005) yaitu perilaku selalu ingin menonton televisi di pagi hari, stress jika jauh dari televisi, selalu memikirkan tayangan televisi, serta selalu menonton televisi sebelum tidur. Hal yang sama diperagakan juga oleh pelaksana kepada peserta sebagai ciri kecanduan internet, terutama mengenai ciri stress jika jauh dari akses internet. Diharapkan melalui demonstrasi ini, anak mendapatkan gambaran perilaku untuk keseimbangan konsumsi media dalam kehidupan sehari-hari mereka dengan mengenali ciri negatif yang bisa dialami jika sudah kecanduan media. 
Kegiatan diskusi dilaksanakan dengan cara tanya jawab disertai hadiah ringan untuk membantu khalayak sasaran menjadi lebih terbuka dalam mengungkapkan pikiran dan perasaannya. Pada kegiatan ini pelaksana berusaha secara terbuka mendengarkan keluh kesah khalayak sasaran sehingga pelaksana dapat mengidentifikasi kendala yang dihadapi khalayak sasaran, serta memberikan arahan solusi untuk mengatasi kendala tersebut. Diketahui bahwa beberapa peserta kegiatan telah memiliki perangkat komunikasinya sendiri dan secara mandiri mengakses media sosial tanpa pendampingan orang tua. Akses media tanpa pendampingan orang tua ini berpotensi mendorong perilaku negatif pada anak karena tidak adanya arahan dan bimbingan orang tua mengenai apa yang boleh dan tidak boleh ditiru oleh anak. Kemudian sebagian besar peserta juga adalah penonton televisi aktif yang melihat tayangan televisi hampir sepanjang hari, kecuali di jam sekolah. Hampir keseluruhan peserta menyatakan bahwa motif mereka menonton televisi adalah untuk mencari hiburan di antara kegiatan harian mereka belajar atau membantu orang tua. Program hiburan jenis variety show adalah program yang diminati paling tinggi dibanding program edukasi atau informasi karena pada umumnya program seperti ini dikemas dengan menarik, ringan dan menampilkan unsur komedi di sepanjang acara.

Dalam sesi diskusi juga diketahui bahwa peserta belum mampu menentukan ukuran kualitas suatu program televisi, serta belum dapat secara mandiri membatasi jam menonton televisi. Peserta sesungguhnya mengetahui bahwa jika suatu tayangan mengandung kekerasan, maka itu bukanlah suatu hal yang patut dicontoh untuk dilakukan kepada rekan sebaya. Akan tetapi pengetahuan tersebut belum mewujud dalam pemahaman dan perilaku karena terdapat situasi di mana sesekali mereka melakukan candaan kekerasan berupa tendangan atau pukulan yang pada akhirnya berakhir dengan pertengkaran sebaya. Dalam sesi diskusi ini diketahui juga bahwa peserta juga telah terpapar tayangan negatif media karena tidak merasa ada yang salah dengan ucapan yang merendahkan fisik atau kondisi sosial seseorang, misalnya memanggil teman dengan jukukan 'si botak' atau 'si rongsok'.

Selain itu, dalam sesi diskusi ini juga diketahui adanya keluhan yang berkaitan dengan kondisi fisik siswa akibat dari penggunaan media. Meskipun hal ini tidak berkaitan dengan potensi konflik sosial, tetapi pelaksana menerima curahan hati peserta yang mengeluhkan fisiknya menjadi mudah lelah, kesulitan tidur di malam hari tapi sebaliknya sangat mengantuk di siang hari, kemudian juga gangguan pada mata yang menjadi mudah merah dan perih akibat terlalu lama menatap layar perangkat seluler mereka saat mengakses media internet.

Solusi yang ditawarkan pada sesi diskusi ini adalah pelaksana memberikan informasi berupa tayangan contoh dengan tujuan agar peserta mengenali ciri tayangan negatif dan tidak menirunya. Peserta juga diarahkan untuk selalu berdiskusi dengan orang dewasa, baik guru maupun orang tua di rumah karena sejalan dengan yang dinyatakan Davidson dalam Munawar et al. (2019) bahwa dalam menggunakan media dengan positif, anak-anak tetap membutuhkan bimbingan orang tua yang mempunyai kecakapan teknis, 
pengetahuan, maupun emosi. Pelaksana juga mengarahkan mengenai dampak apa saja yang muncul jika terus menerus berperilaku negatif kepada teman yang meski disertai alasan ringan, yaitu gurauan, nantinya akan berakhir menjadi konflik antar sebaya di mana salah satu pihak akan merasa tertekan dan tidak mampu menolak perbuatan teman yang merendahkannya. Selain itu peserta juga diajak untuk mengalihkan aktivitas mereka dengan lebih banyak bergerak di luar rumah seperti berolahraga, main sepeda, membantu orang tua, atau aktivitas lainnya sehingga terhindar dari kecanduan media serta dampak lanjutannya yaitu konflik sosial antar sebaya akibat dari peniruan tayangan negatif media massa.

\section{KESIMPULAN}

Kegiatan pemberdayaan masyarakat dengan tema pengenalan literasi media untuk pencegahan konflik sosial pada siswa sekolah dasar di wilayah perdesaan berhasil terlaksana dan mencapai tujuan kegiatan, yaitu tercapainya pengetahuan dan pemahaman yang lebih baik pada anak usia Sekolah Dasar dalam mengakses, menganalisis, mengevaluasi dan mengkomunikasikan pesan dalam berbagai bentuk media komunikasi dan informasi, serta mampu mengendalikan pengaruh media massa dalam kehidupan sehari-hari terutama yang berkaitan dengan interaksi sosial terhadap sesama. Pendekatan yang digunakan adalah komunikasi persuasif dengan bersikap sejajar, memperbanyak diskusi, mengarahkan secara halus, mendampingi, serta mendengarkan keluh kesah para peserta kegiatan sehingga materi kegiatan dapat diterima dengan baik.

Melalui kegiatan pengenalan literasi media ini, khalayak sasaran menjadi tahu bagaimana dapat lebih mandiri mengatur diet media serta pengaturan jadwal akses media secara lebih baik. Hal ini dapat menjadi modal sosial bagi anak dalam interaksinya di masyarakat dengan lebih banyak memiliki niat baik, rasa simpati, perasaan persahabatan, dan hubungan sosial dengan sesama. Meskipun demikian, pendampingan orang tua dan guru akan turut berperan besar dalam mencegah konflik sosial pada anak akibat literasi media yang rendah. Oleh karena itu, diperlukan suatu upaya lainnya untuk mendorong upaya yang seimbang antara literasi media pada anak maupun orang tua dan guru agar dapat bersinergi dalam menghasilkan generasi yang cakap dalam mengakses, menganalisis, mengevaluasi dan membuat pesan dalam berbagai konteks pada media. Dengan hasil kegiatan pemberdayaan ini diharapkan dapat menjadi bahan masukan bagi para pengambil kebijakan agar dapat membuat instrumen diet media bagi anak serta instrumen untuk pengaturan jadwal menonton pada anak, khususnya anak-anak di wilayah perdesaan.

\section{UCAPAN TERIMA KASIH}

Pelaksana berterima kasih kepada seluruh pihak, terutama kepada pihak SDN Panembong 1 dan 2, serta unsur perangkat Desa Panembong yang telah banyak membantu dalam penyelesaian kegiatan pengabdian kepada masyarakat ini. 


\section{DAFTAR RUJUKAN}

Astarini, N., Hamid, S. I., \& Rustini, T. (2017). Studi Dampak Tavangan Televisi Terhadap Perkembangan Perilaku Sosial Anak. Cakrawala Dini: Jurnal Pendidikan Anak Usia Dini, 8(1). https://doi.org/10.17509/cd.v8i1.10554 Bilu, L., A, S., Hamuni, Syahbudin, \& Nerlin. (2018). Pelatihan Penguatan Kelembagaan Ekonomi Masyarakat Melalui Arisan Sapi Di Desa Sawerigadi Kecamatan Barangka Kabupaten Muna Barat. Jurnal Inovasi Hasil Pengabdian Masyarakat (JIPEMAS), 1(2), 137-148. https://doi.org/10.33474/jipemas.v1i2.1518

Chusna, P. A. (2017). Pengaruh Media Gadget Pada Perkembangan Karakter Anak. Dinamika Penelitian: Media Komunikasi Sosial Keagamaan, 17(2), 315-330. https://doi.org/10.21274/dinamika.2017.17.2.315-330

Hariyanti, P. (2017). Literasi Media dan Pembuatan Aturan Pola Konsumsi Media Dalam Keluarga di Desa Sukoreno Sentolo Kulonprogo. AJIE Asian Journal of Innovation and Entrepreneurship, 02(03), 352-363. https://journal.uii.ac.id/ajie/article/view/10859

Hariyanto, F. (2018). Peran Orang Tua dalam Membimbing Anak Menonton Acara Televisi. Jurnal Politikom Indonesiana, 3(2), 179-186. https://doi.org/10.35706/jpi.v3i2.1665

Hendriyani, \& Guntarto, B. (2018). Memetakan Literasi Media di Indonesia. In D. H. Suwarto (Ed.), Gerakan Literasi Media di Indonesia. Rumah Sinema. http://staffnew.uny.ac.id/upload/132309682/penelitian/Buku Gerakan Literasi.pdf

Kunandar, A. (2014). Model Literasi Media Pada Anak dalam Mencegah Konflik Sosial. Jurnal Komunikasi Profetik, 7(1), 87-99. http://ejournal.uinsuka.ac.id/isoshum/profetik/article/view/1117

Mas'Amah, \& Hana, F. T. (2018). Literasi Media Kader Posyandu di Desa Oeltua Kecamatan Taebenu Kabupaten Kupang Provinsi Nusa Tenggara Timur. Seminar Nasional Fantasi Multikultur.

Munawar, M., Fakhruddin, RC, A. R., \& Titi Prihatin. (2019). Keterlibatan Orangtua dalam Pendidikan Literasi Digital Anak Usia Dini. Seminar Nasional Pascasarjana 2019, 1-5. https://proceeding.unnes.ac.id/index.php/snpasca/article/view/272/235

Musfira. (2018). Gangguan Emosional Anak Akibat Tayangan Misteri Televisi (Studi Kasus Pada Anak Usia 2-11 Tahun). PEMBELAJAR: Jurnal IImu Pendidikan, Keguruan, Dan Pembelajaran, 2(2), 132-137. https://doi.org/10.26858/pembelajar.v2i2.7164

Novianti, R., \& Riyanto, S. (2018). Tingkat Literasi Media Remaja Desa Dalam Pemanfaatan Internet. Jurnal Komunikasi Pembangunan, 16(2), 158171. https://doi.org/10.46937/16201825628

Orange, T., \& O'Flynn, L. (2005). The Media Diet For Kids (Terjemahan). PT. Serambi Ilmu Semesta.

Rahardjo, T., Birowo, M. A., \& Darmastuti, R. (2012). Literasi media dan kearifan lokal: konsep dan aplikasi (Pertama). Buku Litera.

Raturahmi, L. (2018). Perilaku Penggunaan Media Massa Pada Masyarakat Perdesaan. Jurnal Riset Komunikasi JURKOM, 1(2), 213-224. 
https://doi.org/10.24329/jurkom.v1i2.33

Setyaningsih, R. (2017). Model Literasi Media Berbasis Kearifan Lokal Pada Masyarakat Kampung Dongkelan Kauman Daerah Istimewa Yogyakarta. Komuniti: Jurnal Komunikasi Dan Teknologi, 9(2), 118-125. https://doi.org/10.23917/komuniti.v9i2.4520

Suparlan, P. (2006). Konflik Sosial dan Alternatif Pemecahannya. Antropologi Indonesia, 30(2), 138-150. https://doi.org/10.7454/ai.v30i2.3559

Triwardhani, I. J. (2006). Komunikasi Persuasif pada Pendidikan Anak. Mediator: Jurnal Komunikasi, 7(1), 77-84. https://doi.org/10.29313/mediator.v7i1.1220 